\title{
BNREL
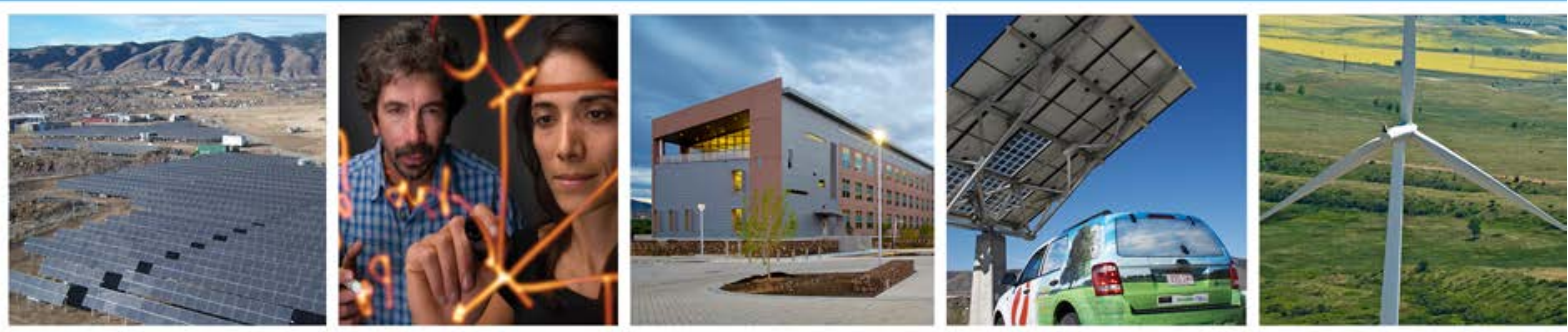

\section{Improved Offshore Wind Resource Assessment in Global Climate Stabilization Scenarios}

Douglas Arent

National Renewable Energy Laboratory, Joint Institute for Strategic Energy Analysis

Patrick Sullivan, Donna Heimiller, Anthony Lopez, and Kelly Eurek National Renewable Energy Laboratory

Jake Badger, Hans Ejsing Jørgensen, and Mark Kelly

DTU Wind Energy

Leon Clarke and Patrick Luckow Pacific Northwest National Laboratory 


\section{Improved Offshore Wind Resource Assessment in Global Climate Stabilization Scenarios}

Douglas Arent

National Renewable Energy Laboratory, Joint Institute for Strategic Energy Analysis

Patrick Sullivan, Donna Heimiller, Anthony Lopez, and Kelly Eurek National Renewable Energy Laboratory

Jake Badger, Hans Ejsing Jørgensen, and Mark Kelly

DTU Wind Energy

Leon Clarke and Patrick Luckow

Pacific Northwest National Laboratory

Prepared under Task No. SA10.102E
National Renewable Energy Laboratory 15013 Denver West Parkway Golden, Colorado 80401 303-275-3000 • www.nrel.gov
NREL is a national laboratory of the U.S. Department of Energy, Office of Energy Efficiency \& Renewable Energy, operated by the Alliance for Sustainable Energy, LLC.

Technical Report NREL/TP-6A20-55049

October 2012

Contract No. DE-AC36-08G028308 


\section{NOTICE}

This report was prepared as an account of work sponsored by an agency of the United States government. Neither the United States government nor any agency thereof, nor any of their employees, makes any warranty, express or implied, or assumes any legal liability or responsibility for the accuracy, completeness, or usefulness of any information, apparatus, product, or process disclosed, or represents that its use would not infringe privately owned rights. Reference herein to any specific commercial product, process, or service by trade name, trademark, manufacturer, or otherwise does not necessarily constitute or imply its endorsement, recommendation, or favoring by the United States government or any agency thereof. The views and opinions of authors expressed herein do not necessarily state or reflect those of the United States government or any agency thereof.

Available electronically at http://www.osti.gov/bridge

Available for a processing fee to U.S. Department of Energy and its contractors, in paper, from:

U.S. Department of Energy Office of Scientific and Technical Information P.O. Box 62

Oak Ridge, TN 37831-0062

phone: 865.576.8401

fax: 865.576 .5728

email: mailto:reports@adonis.osti.gov

Available for sale to the public, in paper, from:

U.S. Department of Commerce National Technical Information Service 5285 Port Royal Road Springfield, VA 22161 phone: 800.553 .6847 fax: 703.605.6900

email: orders@ntis.fedworld.gov online ordering: http://www.ntis.gov/help/ordermethods.aspx

Cover Photos: (left to right) PIX 16416, PIX 17423, PIX 16560, PIX 17613, PIX 17436, PIX 17721

Printed on paper containing at least $50 \%$ wastepaper, including $10 \%$ post consumer waste. 


\section{Abstract}

This paper introduces a technique for digesting geospatial wind-speed data into areally definedcountry-level, in this case - wind resource supply curves. We combined gridded wind-vector data for ocean areas with bathymetry maps, country exclusive economic zones, wind turbine power curves, and other datasets and relevant parameters to build supply curves that estimate a country's offshore wind resource defined by resource quality, depth, and distance-from-shore. We include a single set of supply curves - for a particular assumption set — and study some implications of including it in a global energy model.

We also discuss the importance of downscaling gridded wind vector data to capturing the full resource potential, especially over land areas with complex terrain. This paper includes motivation and background for a statistical downscaling methodology to account for terrain effects with a low computational burden. Finally, we use this forum to sketch a framework for building synthetic electric networks to estimate transmission accessibility of renewable resource sites in remote areas. 


\section{Table of Contents}

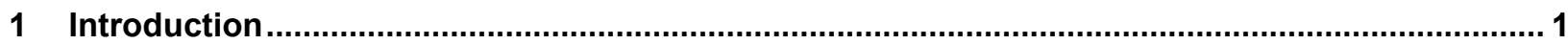

2 Modeling Renewable Energy Technologies and the Energy System: Scope and Detail ............. 2

3 Assessment of the Size and Quality of the Renewable Resource Potential ............................... 3

3.1 Supply Curve Comparison: Harvard Global Wind Potential Study............................................... 5

3.2 Updated Offshore Wind Resource Assessment .................................................................... 7

4 Exploration of Statistical Downscaling to Create Improved Supply Curves................................. 9

5 Accounting for Geographic Integration Costs to Develop the Potentials ............................... 12

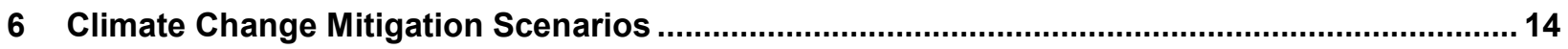

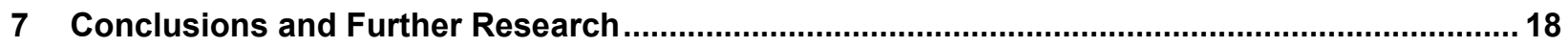

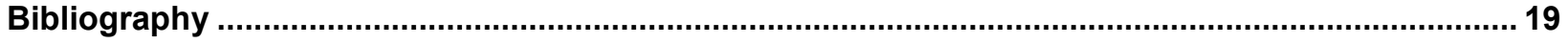

Appendix A: Global Wind Potential Supply Curves by Country, Class (Binned by Annual Average

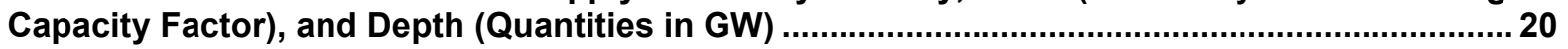




\section{Introduction}

Limiting and reducing emissions of greenhouse gases (GHG) to mitigate global climate change is to a large part a long-term challenge affecting the global energy sector. Renewable energy technologies have the potential to contribute substantially to supplying energy at low GHG emissions. The 2011 Special Report on Renewables by the Intergovernmental Panel on Climate Change (IPCC) ${ }^{1}$ reviewed the published scientific global scenario literature that covers a large number of Integrated Assessment Models (IAMs). It finds considerable variations of renewable energy technology deployment levels for the coming decades ranging from negligible to substantial: some scenarios exceed $400 \mathrm{EJ} /$ year of renewable energy, up from about $64 \mathrm{EJ}$ in 2008 (IPCC 2011). The report documents substantial knowledge gaps with respect to (1) the economic resource potential under various scenarios of future development, and (2) the potential role of renewable energy technologies in the context of an integrated climate change mitigation strategy. This paper summarizes initial steps to improving the robustness and accuracy of such global resource and techno-economic assessments. Specifically, this paper deals with wind resource assessments: the development of an algorithm to construct country-level resource supply curves, delineated by resource quality and other parameters; introduction of specific offshore wind supply curves; and progress updates in two areas of ongoing research for improving the fidelity of onshore assessments.

Ongoing energy-economic analysis at the country, regional, and international levels, including the activities of the Energy Modeling Forum, the Integrated Assessment Modeling Consortia, and many independent policy and technology analysis activities, plus the upcoming publication of the fifth assessment report (AR5) of the IPCC in 2014, represents the breadth of related research of climate change mitigation strategies and other related policy and technology analyses. These policy-relevant research tasks address key questions related to the role of energy technologies for climate mitigation (as well as a host of additional policy goals) and offer the opportunity to address knowledge gaps to more accurately assess the potential role of renewable energy in deployment scenarios. In particular, scenarios developed with IAMs that deploy wind and solar energy resources at large scale and integrate these variable sources into the electricity system can be substantially improved. The final section of this paper is an analysis of the impacts of a new resource assessment on a set of scenarios of an IAM, the Global Change Assessment Model (GCAM).

\footnotetext{
${ }^{1}$ IPCC Special Report on Renewable Energy Sources and Climate Change Mitigation: http://srren.org
} 


\section{Modeling Renewable Energy Technologies and the Energy System: Scope and Detail}

In order to model renewable energy technologies in a way that is relevant to policymakers and other stakeholders, the system under consideration needs both scope and detail. Scope-having system boundaries wide enough to include global and economy-wide interactions: economic development, trade, GHG restrictions or incentives for low-GHG solutions, electrification (in reference to both countries and economic sectors) - allows feedback, systemic change, and policy levers to operate within the model. Meanwhile, detail in resource availability, technology performance, and the impact on reliability of integrating renewable technologies into the electric grid are necessary for the model to properly choose among technology options.

This paper presents initial results of a collaborative effort to incorporate more accurate resource potential estimates and improve technological representation in integrated assessment models while maintaining their long-term and global perspective. One of the major challenges for largescale scenario modeling (e.g., national, regional, or global) is to capture the geospatial detail of renewable energy resources both for resource potential and economic calculus of the spatial dependencies such as transmission costs. Specifically, the key goals include: (1) robust assessments of the size and quality of the renewable resource potential; (2) representation of challenges related to constraints, costs, and the integration of fluctuating renewable electricity sources into existing electric power systems; and (3) the generation of new climate change mitigation scenarios, including the improved representation of renewable energy given different assumptions on climate and energy policy frameworks. 


\section{Assessment of the Size and Quality of the Renewable Resource Potential}

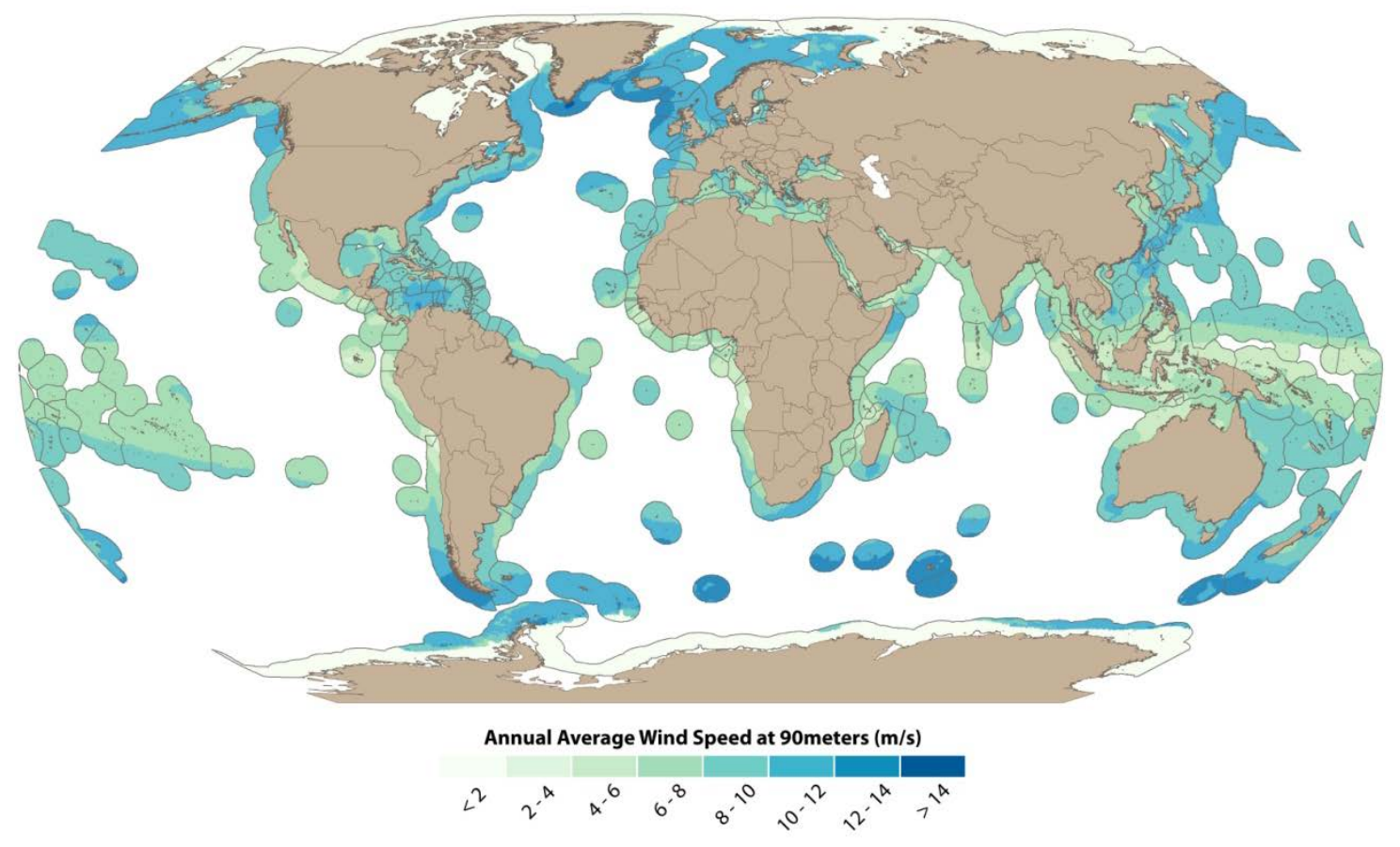

Figure 1. Blended Sea Winds annual average wind speed map; adjusted to $90-\mathrm{m}$ hub height

Both on- and offshore wind are important technology options for renewable electricity production. For this initial study, we develop offshore wind supply curve estimates - as the technology is maturing rapidly and represents an important option to be incorporated in scenario analysis - and present initial work toward improving the resource potential of onshore wind for global analysis.

For offshore wind, we used NOAA's Blended Sea Winds ${ }^{2}$ global offshore wind dataset. The dataset contains ocean surface vector winds and wind stresses gridded at $0.25^{\circ}$. Multiple time resolutions are available: 6-hour, daily, and monthly. Wind speeds were generated from satellite observations; directions, from a combination of National Centers for Environmental Prediction (NCEP) Reanalysis and European Center for Medium-Range Weather Forecasts (ECMWF) data assimilation products.

Hub height is an important determinant of wind resource at a given location. Due to drag close to ground-level, wind speeds fall at lower altitudes. Over rough terrain, that drop can be precipitous, but there is substantial drag even over relatively smooth ocean surfaces. Wind speeds in the Blended Sea Winds database are at $10 \mathrm{~m}$ above ground level. To extrapolate them to higher hub heights, we applied a power-law wind-shear adjustment using a shear exponent of

\footnotetext{
${ }^{2}$ Zhang, H.-M.; Reynolds, R.W.; Bates, J.J. (2006). "Blended and Gridded High Resolution Global Sea Surface Wind Speed and Climatology from Multiple Satellites: 1987 - Present.” American Meteorological Society 2006 Annual Meeting, January 29 - February 2, 2006, Atlanta, GA; Paper \#P2.23.
} 
0.11. The exponent value was chosen based on the guidance of Schwartz et al. (2010), who support its use for U.S. marine areas. The coarseness of the escalation assumption is regretful but necessary given this dataset; future analysis will use a different source dataset that includes wind speeds modeled at multiple heights such that it needs only interpolation over small height increments.

Moving from wind speed to supply curves that can be easily incorporated into energy-economic models and IAMs involves multiple steps. These supply curves use annual expected capacity factor (full load hours) as the metric of wind quality. Averaging over monthly wind speed produced annual average wind speed. There were some missing months in the dataset, especially at polar latitudes. For cells with at least 10 months of data, we took the 10-month average as the annual average; for cells with fewer than 10 months of data, we gave no resource. As those grid cells tended to be at extreme northern latitudes, and the missing months were generally in winter, we took the gaps to be ice-caused and regarded those sites as too icy for economic wind development. We were unable to address seasonal adjustments for missing months, which may introduce an unintended bias for those cells we prorated to cover a missing month or two.

As a representative power curve for converting wind speed to power output, we chose an IEC Class I Composite 3.5-MW turbine (power curve represented in Figure 2). Given that the raw data was mean monthly wind speed, we needed to make an assumption about the distribution of speeds: a wind speed distribution based on the mean wind speed for the grid cell and a Weibull-k parameter of 2.0, convolved with the representative power curve, produced annual power output, from which annual average capacity factor was rendered. The dataset for the next generation analysis contains hourly timeseries and therefore will incorporate endogenous distribution estimates.

Other losses of output, namely those associated with availability and wake losses, are worth accounting for. Availability captures the percentage of time during a year for which a turbine will be available for operation while the local wind speed is above the minimum level necessary for power production. Hoogwijk et al. (2004) use an availability of 0.95 (i.e., a turbine will only be operational for $95 \%$ of the full-load hours in a year due to maintenance and breakdowns). Other turbine power losses result from the design of the wind farm turbine array. Air flow interference can result when turbines are located too close in proximity. The turbine array efficiency reflects the losses due to the turbine array design. Hoogwijk et al. (2004) give 0.9 for

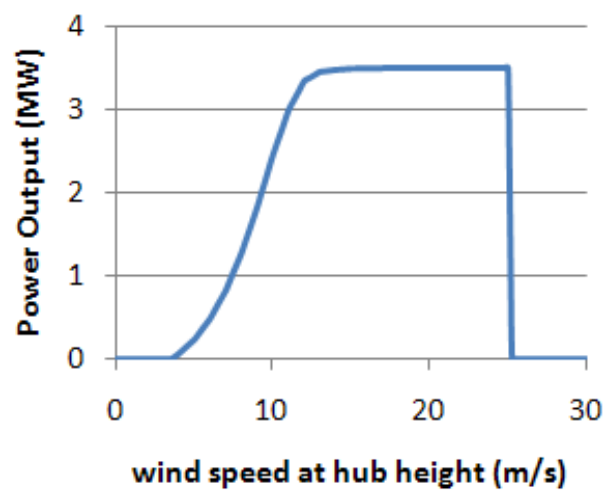

Figure 2. Power curve for IEC Class I composite 3.5-MW wind turbine the array efficiency (i.e., 10\% of the turbine power will be lost due to wake losses). For bathymetry, we used the ETOPO1 1 Arc-Minute Global Relief Model ${ }^{3}$ to estimate water depth for each grid cell. The supply curve is binned according to ocean depth to differentiate among different turbine-infrastructure regimes. In order to assign offshore resource to specific

\footnotetext{
${ }^{3}$ Amante, C.; Eakins, B.W. (2009). ETOPO1 1 Arc-Minute Global Relief Model: Procedures, Data Sources and Analysis. NOAA Technical Memorandum NESDIS NGDC-24, March 2009; 19 pp.
} 
countries, we used the VLIZ Maritime Boundaries Geodatabase to define exclusive economic zones (EEZs) for offshore regions. Legal EEZs extend up to 200 nautical miles from the coastline.

Not all windy maritime area is suitable for wind development. Shipping lanes and maritime protected areas, for instance, are unlikely locations for wind farms. We identified heavily traveled shipping lanes, as determined from a density analysis of the shipping tracks database developed by the National Center for Ecological Analysis and Synthesis. ${ }^{4}$ Shipping density was measured in kilometers of tracks per square kilometer, then reclassified into three categories; 0 $3,5-15$, and $>15 \mathrm{~km}$ per $\mathrm{km}^{2}$. Limitations with the shipping-lane database forced us to ignore that data layer for this analysis; we hope to remedy those issues and consider shipping lane exclusions for the next round. Protected areas were mapped from a database by Protected Planet, ${ }^{5}$ with areas were identified by their International Union for the Conservation of Nature (IUCN) rankings.

To convert from available surface area to wind potential in nameplate-capacity terms, we applied a uniform factor of $5 \mathrm{MW} / \mathrm{km}^{2}$. This conversion represents turbine spacing of approximately eight rotor diameters (Musial and Ram 2010). As the assumptions are sourced from different studies, an eight-rotor array spacing may not relate directly to the assumed $10 \%$ array losses. Musial and Ram are coy, stating only that "the community is still determining the optimal spacing with no consensus yet" and elsewhere that "[a]rray losses of more than $10 \%$ for offshore wind farms have been documented."

These assumptions (representative power curve, hub height, exclusions, turbine density) and other parameters - minimum and maximum distance from shore, maximum water depth, and Weibull shape parameter - are all embedded in an algorithm that draws from a spatially enabled PostgreSQL database. The database contains the gridded wind speed information, along with bathymetry, distance from shore, and shipping-lane and protection status. The script that processes the algorithm is easily modified to allow different assumptions to guide the development of supply curves. As such, this paper presents two different sets of supply curves generated through the algorithm. The first, only a partial presentation, aligns assumptions with those in the Harvard global wind assessment by Lu et al. (2009) for the purposes of comparing the two databases and methods. The second, which we present in its entirety in the appendix, is described in detail below.

\subsection{Supply Curve Comparison: Harvard Global Wind Potential Study}

The Harvard study by Lu et al. (2009) used version 5 of the Goddard Earth Observing System Data Assimilation System (GEOS-5) database for wind speeds to produce onshore and offshore wind supply curves. They assumed hub heights of $100 \mathrm{~m}$ and interpolated between the vertical layers of the GEOS-5 pressure fields to produce them. Accordingly, we scaled wind speeds to a 100-m hub height. We also matched the Harvard study's limit of 50 nautical miles from shore, water depth limit of $200 \mathrm{~m}$, and a resource cutoff at $20 \%$ annual average capacity factor. The

\footnotetext{
4 “Data: Impacts.” National Center for Ecological Analysis and Synthesis, last modified March 21, 2011. http://www.nceas.ucsb.edu/globalmarine/impacts

${ }^{5}$ IUCN and UNEP (2010). The World Database on Protected Areas (WDPA). Cambridge, UK: UNEP-WCMC. www.protectedplanet.net
} 
Harvard study did not exclude protected areas from their assessment, so we left them out as well, for consistency.

Table 1. Comparison of Offshore Wind Resource Potential for Top $10 \mathrm{CO}_{2}$-Emitting Countries between NREL-Aligned and Harvard Studies. All depth categories (to $200 \mathrm{~m}$ ); resource in annual wind energy potential.

\begin{tabular}{lrr} 
& Potential wind energy (TWh) \\
\cline { 2 - 3 } & NREL & Harvard \\
\hline United States & 17,200 & 14,000 \\
\hline China & 7,800 & 4,600 \\
\hline Russia & 18,000 & 23,000 \\
\hline Japan & 5,300 & 2,700 \\
\hline India & 1,100 & 1,100 \\
\hline Germany & 300 & 940 \\
Canada & 10,600 & 21,000 \\
United & 8,600 & 6,200 \\
Kingdom & 1,700 & 990 \\
South Korea & 800 & 160 \\
\hline Italy & 192,800 & 157,000 \\
\hline Global & &
\end{tabular}

The Harvard study assumed 3.6-MW GE turbines and a turbine density of $5.84 \mathrm{MW} / \mathrm{km}^{2}$; we maintained the $3.5-\mathrm{MW}$ turbine and $5-\mathrm{MW} / \mathrm{km}^{2}$ density from our standard assumptions. Turbine size does not directly impact the results; density does, but only by the ratio of 5.84/5. If all else were equal, the Harvard study would show $17 \%$ more resource than this NREL analysis. Table 1 shows total wind resource potential out to $50 \mathrm{~nm}$ and for all depth classes to $200 \mathrm{~m}$ for the top 10 $\mathrm{CO}_{2}$-emitting countries; Table 2 shows wind resource potential by depth class globally and for the continental United States. For Table 2, we matched the depth classes used in the Harvard study: shallow $(0-20 \mathrm{~m})$, transitional $(20-50 \mathrm{~m})$, and deep $(50-200 \mathrm{~m})$.

Table 2. Comparison of Offshore Wind Resource Potential Globally and for Continental United States Between NREL-Aligned and Harvard Studies. Annual wind potential by depth class.

\begin{tabular}{lrrrr} 
& \multicolumn{4}{c}{ Potential wind energy (TWh) } \\
\cline { 2 - 5 } & $\begin{array}{r}\text { NREL } \\
\text { Global }\end{array}$ & $\begin{array}{r}\text { Harvard } \\
\text { Global }\end{array}$ & NREL US48 & Harvard US48 \\
\hline Shallow (0-20 $\mathbf{~})$ & 41,200 & 42,000 & 1,500 & 1,200 \\
\hline Transitional $(\mathbf{2 0 - 5 0} \mathbf{~ m})$ & 51,300 & 40,000 & 1,900 & 2,100 \\
Deep (50-200 $\mathbf{m})$ & 100,300 & 75,000 & 2,100 & 2,200 \\
\hline Total & 192,800 & 157,000 & 5,500 & 5,500 \\
\hline
\end{tabular}

Magnitude of potential resource generally aligns between the two studies, with the Harvard study including somewhat less resource globally than the aligned NREL assessment. Some of the greatest differences are among the countries with large northern borders, Canada and Russia, where the NREL database excludes some extreme-northern sea area. Germany takes a smaller hit, but some of its North Sea area is excluded because of missing data. Totals for the United States differ between the two tables because only Table 1 includes Alaska and Hawaii. 


\subsection{Updated Offshore Wind Resource Assessment}

Using the same Blended Sea Winds database, but with some altered processing assumptions (described below), we created a second set of supply curves. Assumptions that differ in this assessment from those in the Harvard comparison include a hub height of $90 \mathrm{~m}$, maximum water depth of $1,000 \mathrm{~m}$, and a minimum resource cutoff of $8.0 \mathrm{~m} / \mathrm{s}$ annual average wind speed (replacing the $20 \%$ annual capacity factor used in the aligned assessment). In addition, we deepened the depth classes to correspond to those used by Musial and Ram (2010): shallow (0$30 \mathrm{~m}$ ), transitional (30-60 m), and deep (60-1,000 m), and we extended the maximum distance from shore to 100 nautical miles. As mentioned above, we did not exclude shipping lanes in this analysis because of limitations in the database of shipping tracks, but we did exclude protected areas with IUCN codes of I-III. The protected areas amounted globally to about $5 \%$ of the total considered area within 100 nautical miles of shore. We also excluded all area within 5 nautical miles of shore as a coarse application of public resistance to visual disturbance. These supply curves are delineated in nameplate capacity terms rather than annual energy output, and wind classes are differentiated by annual average capacity factor.

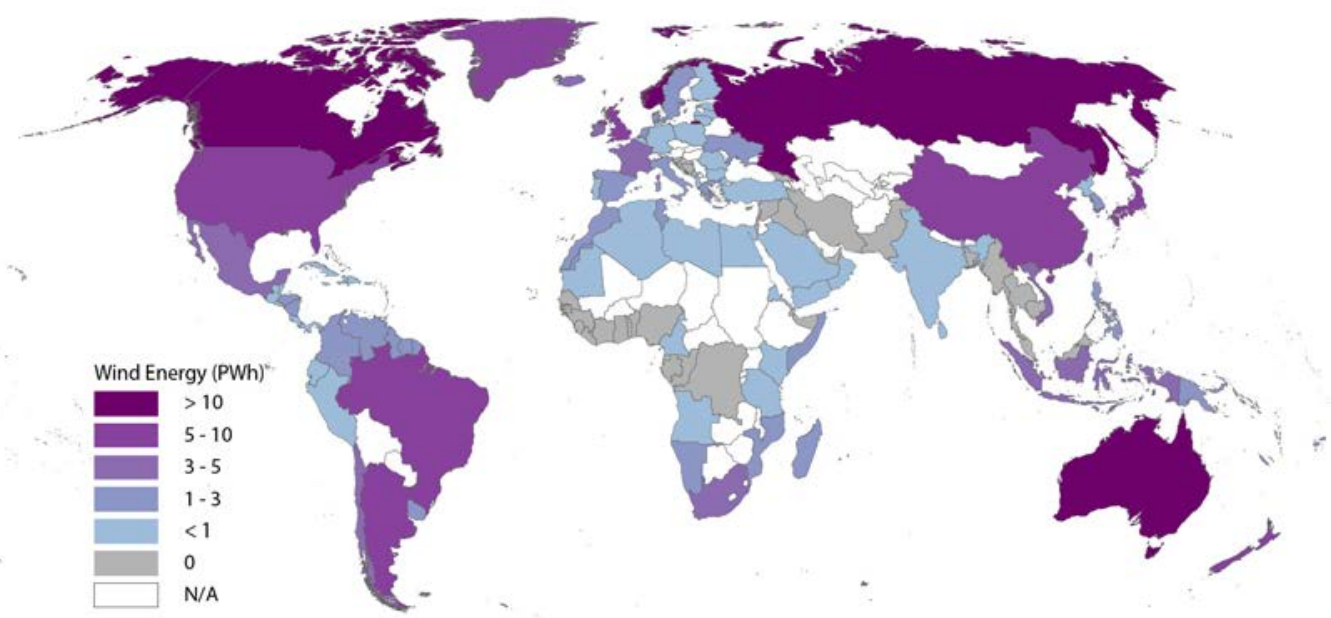

Figure 3. Offshore wind potential by country (PWh), all resource and depth classes

The complete country-by-country supply curve, indexed by wind class and depth, is re-created in Appendix A. Figure 4 includes selected countries, generally larger economies with substantial wind resources. The entry for the United States includes only the continental United States. Alaska has more apparent potential than the continental United States in this assessment, but its distance from continental United States loads makes potential development of Alaskan wind resource fundamentally different, and worth keeping separate. 


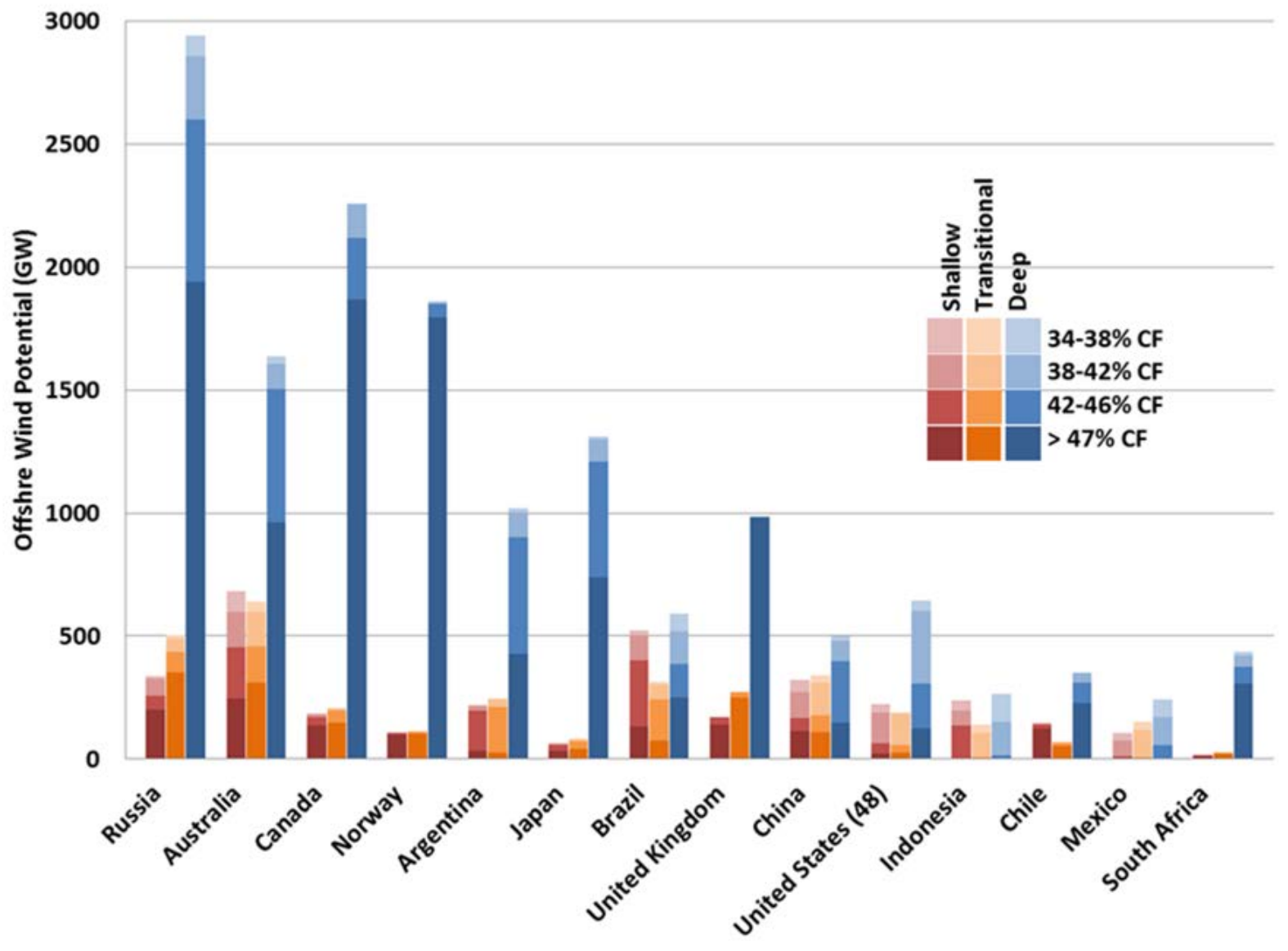

Figure 4. Wind potential (GW) by wind resource class (annual-average capacity factor bin) and water depth for selected countries 


\section{Exploration of Statistical Downscaling to Create Improved Supply Curves}

In addition to the offshore wind assessment presented above, we are working on developing onshore wind supply curves that more accurately reflect the fine geospatial dependencies of wind resources, which present an additional challenge. Estimating wind resource in complex terrain areas, especially mountainous regions, is challenging because small-lengthscale terrain features can strongly affect the path and strength of local winds (Landberg et al. 2003). The reanalysis datasets typically used for regional or global wind assessments do not have sufficient resolution to resolve windward and leeward faces of steep features and properly assess the terrain-induced acceleration thereof. Without such features included, such datasets tend to miss both the highresource terrain-accelerated areas and low-resource alee areas, lumping them together as regions of intermediate quality.

Methods exist to reanalyze coarse datasets with high-resolution terrain information but have limitations in either fidelity or computational expense. Classical wind downscaling techniques were developed for low-to-moderate slopes and are less effective when applied to steep and complex terrain. Particularly steep areas where wind flow separates from the terrain or leeward areas where winds are dominated by recirculation are not well-resolved in flow- or numerical downscaling models. In contrast, detailed computational fluid dynamic modeling, with explicit and comprehensive modeling of wind flows, are resource-intensive. While they work effectively for limited areas, they are currently too time-consuming and expensive to apply to large regions that span the globe.

Because a global resource assessment for integrated assessment modeling requires even-handed treatment of all areas, we are investigating downscaling techniques with some capability to account for complex terrain while remaining computationally reasonable over large areas. This investigation includes microscale linearized flow models, ${ }^{6}$ dynamic mesoscale models, ${ }^{7}$ terrainbased statistical methods, and combinations thereof.

The Technical University of Denmark (DTU) Wind Energy meteorology team has performed initial experiments on terrain-spectral statistical approaches to downscaling coarse reanalysis wind speed data. As introduced by Badger and Jørgensen (2011), the simple spectral orography model (SSOM) estimates the terrain-induced spatial wind variance in a mesoscale grid cell based on variation in elevation. The simple geostrophic drag model (SGDM) applies geostrophic drag, based on surface roughness, to estimate the variance in wind speeds due to roughness. The total spatial variance in wind speed over the grid cell is taken to be the sum of the variances from the SSOM and SGDM. The theory behind the method is that there is a relationship between terrain elevation and roughness and expected spatial distributions of wind power. Recognizing that terrain-induced speedup is caused by features on scales generally less than $10 \mathrm{~km}$, and that terrain spectra are monotonically decreasing over those scales (usually describable by one or two power-laws, particularly for ring-averaged spectra), we generalize this concept to the terrain spectrum for the range of scales between $10 \mathrm{~km}$ down to a scale that is twice the map resolution. For linearized flow models, in many cases a terrain spectrum can also be translated into an

\footnotetext{
${ }^{6}$ WASP: http://www.wasp.dk/

${ }^{7}$ WRF: $\underline{\text { http://www.wrf-model.org/index.php }}$
} 
expected distribution of relative speed-ups - or into the cumulative distribution of wind power densities relative to a domain-averaged power density. Application of this approach allows one to statistically estimate the wind power density (in $\mathrm{W} / \mathrm{m}^{2}$ ), leading to wind power in $\mathrm{PW}$ at each resource-quality level for a given grid cell. Additionally, technical resource estimates rely on knowledge of high-quality resource areas and ignore low-quality resource areas; fractiles of power density conform well to that need.

Over several test areas in Denmark, Spain, and China, the DTU team developed a technique of rescaling wind power density distributions based on the underlying terrain features. Given a lowresolution wind power distribution, new spatially based distributions can be estimated that account for orography and surface roughness.

The statistical downscaling technique was applied over multiple small, $50 \mathrm{~km}$ x $50 \mathrm{~km}$ test areas, and shows reasonable agreement - with distributions reached through physical model downscaling - for most, but not all, types of terrain features within the limited initial test areas, as shown in Figure 5.

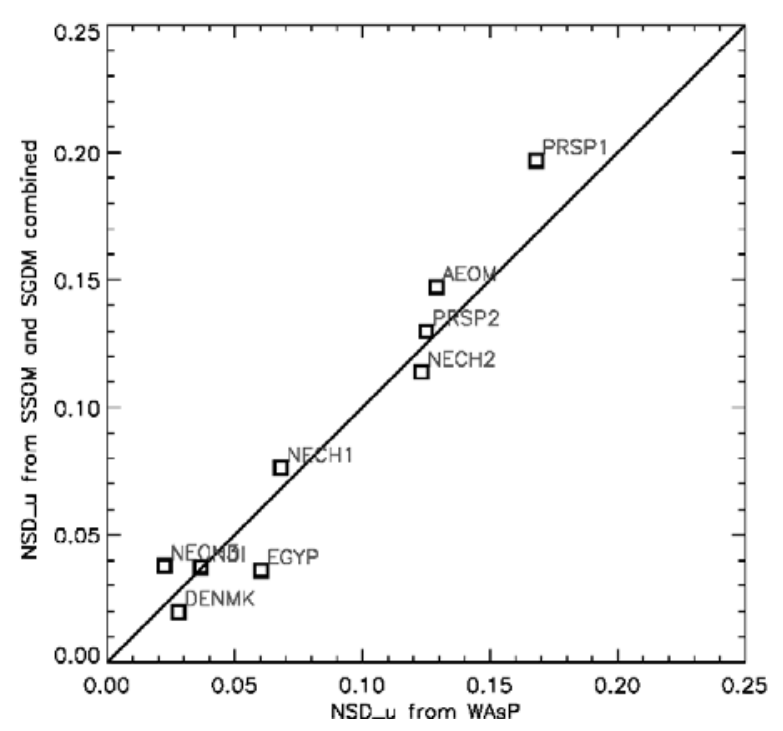

Figure 5. Normalized standard deviation (NSD) of statistically-calculated wind power density (SSOM and SGDM) compared to that obtained from full WAsP modeling for nine test areas
Further testing of this approach is being conducted on the complex terrain of the Columbia Gorge, in the Northwest United States. The $650 \mathrm{~km}$ x $400 \mathrm{~km}$ test area extends from the Pacific Ocean inland over several mountain ranges and includes the large valley defined by the Columbia River. Initial results showing the distribution of the highest power density areas are shown in Figure 7. As this work is ongoing, quantitative results are not yet available. Nevertheless, comparing the left and right maps in Figure 7 shows clearly that wind-speed information at the sub-grid-cell level can reveal the existence of areas of higher-quality resource than the area average. While this statistical downscaling method does not pinpoint physical location of high-quality resource in the way that the dynamically downscaled map in Figure 8 does, it can be useful if the data are to be aggregated into supply curves. The algorithm testing currently

underway aims to determine whether this statistical method can produce large-area supply curves that approximate those created through more computationally intensive methods. 

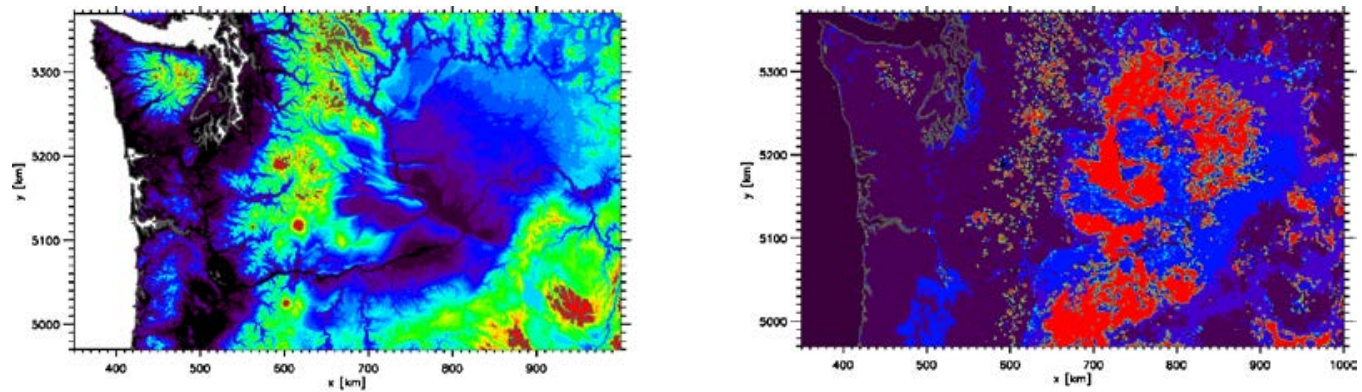

Figure 6. Orography (left) and surface roughness (right) of the $650 \mathrm{~km} \times 400 \mathrm{~km}$ Columbia Gorge test area located in northwest United States. Elevation (on left) ranges from 0 to above $200 \mathrm{~m}$; for surface roughness, darker equals rougher.
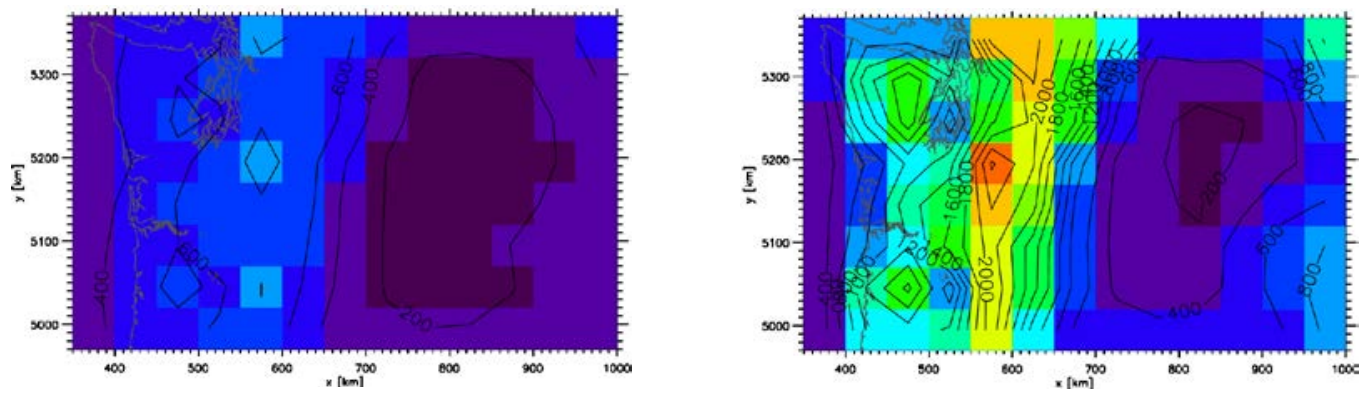

Figure 7. Wind power density $\left(\mathrm{W} / \mathrm{m}^{2}\right)$ at $50 \mathrm{~m}$ (left) accounting for spatial and temporal variance. Wind power density at $50 \mathrm{~m}$ for windiest $10 \%$ of area (right).

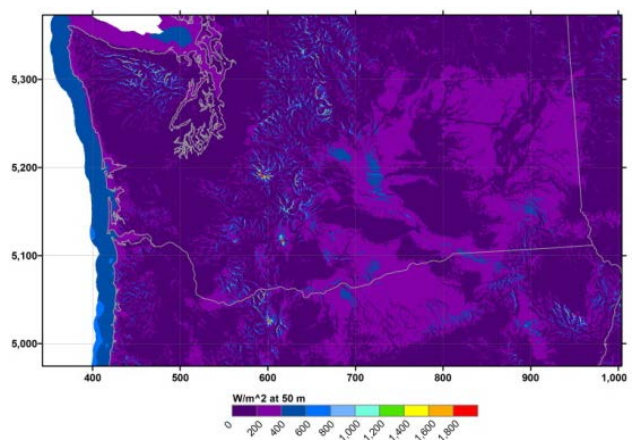

Figure 8. Wind power density $\left(\mathrm{W} / \mathrm{m}^{2}\right)$ at $50 \mathrm{~m}$ from NREL/AWS Truepower wind resource assessment, $200-\mathrm{m}$ spatial resolution 


\section{Accounting for Geographic Integration Costs to Develop the Potentials}

The deployment of renewables comes with three main problems: competition with other land-use purposes including human uses and environmental protection; cost of installing, operating, and maintaining the generating facilities; and challenges of integrating renewable power sources into the existing electric sector while maintaining reliable power provision. Though the theoretical developable potential of renewable energy sources is important, it is crucial to consider the spatial heterogeneity and temporal variability of supply when designing models to make economic-based projections of renewable power deployment. In particular, resource supply curves should account for differences in the costs associated with developing different resource sites. In regions with robust electric grids, this would be the cost of connecting a potential facility to the existing network; in a region without, it would be the cost of connecting it directly to a load. To incorporate connection cost as a dimension in resource supply curves, we are developing a methodology to estimate accessibility for resource at each grid cell. We present initial results on the development of methods to determine synthetic transmission grids, particularly for countries and regions where high-quality transmission grid data is not available, and apply techno/economic algorithms for inclusion in climate/energy modeling frameworks.

Initial analysis to develop a proxy for major global transmission lines utilizes publicly available global data on power plants available through the Carbon Monitoring for Action (CARMA) website (http://www.carma.org) and the locations of large urban areas with populations greater than 50,000. CARMA publishes the power plant location coordinates, present annual generation, and annual carbon emissions. Large power plants were identified based on the annual generation, limiting the analysis to plants with generation of 200,000 MWh and greater (approximately a 25MW plant with a $90 \%$ capacity factor). The data does not include the fuel type of the power plant, so no modifications to account for variance based on fuel type could be applied.

The power plant and urban area locations were compiled into a database representing nodes, and links created between the nodes to generate a simplified synthetic transmission grid. Rules for linking the nodes were empirically developed based on multiple iterations and visual evaluation of the results in areas where existing transmission line data was available for comparison. Each node links to the two closest nodes, regardless of type of node (power plant or urban area). Isolated networks that were within $200 \mathrm{~km}$ of another node network were joined together based on the shortest distance between the networks, eliminating artificial islands caused by dense clusters of nodes. Finally, a maximum link distance of $500 \mathrm{~km}$ was applied to prevent linking in isolated nodes in remote areas. Representative comparative results are shown in Figure 9. We observe relatively good qualitative agreement and note that while the synthetic network is not as dense, it can approximate major arteries. Line density can be increased by including more cities; however, further work will be required to develop adequately robust representation to incorporate into quantitative analysis. 

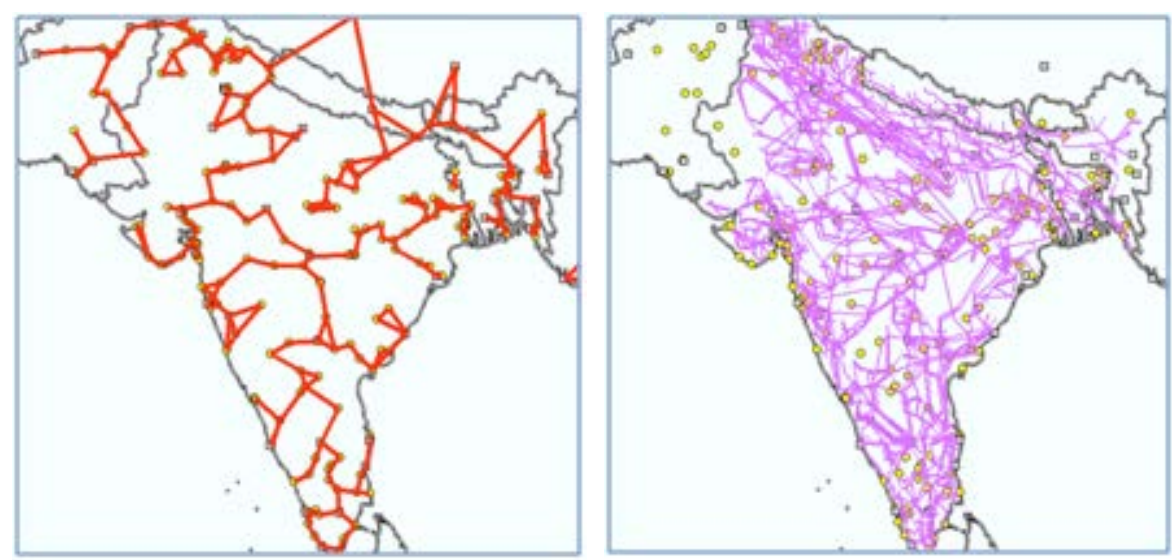

Figure 9. Results comparing synthetic grid (left) to available mapped grid lines (right) for India, Nepal, and Bangladesh 


\section{Climate Change Mitigation Scenarios}

The assessment of renewables for climate change mitigation must also go beyond the technical perspective and must take into consideration the interrelationship with the broader economic system. The overall demand for renewable electricity depends on economic development, the degree of electrification, and the availability and performance of alternative technologies. Moreover, the policy frameworks are essential for the deployment of renewables and the effect on GHG emissions and prices.

The use of high-quality data for resource potentials, as described above, as well as the improved representation of challenges of constraints, costs, and integration will make it possible to generate advanced climate change mitigation scenarios that will provide new insights about the role of renewable energy under a number of alternative, self-consistent future development pathways, and make it possible to derive key determinants for its deployment.

Here, we present a first round of results from the Global Change Assessment Model (GCAM), a recursive-dynamic IAM of economy, energy, and land-use from the Pacific Northwest National Laboratory (PNNL). GCAM explicitly models markets in the energy and industrial system and solves for equilibrium prices in those areas as well as cross-industry goods such as emissions. GCAM is a long-term model, operating through 2095 with regional resolution of 14 distinct regions across the globe. For a thorough description of how the GCAM models the energy production, transformation, and demand systems, see Clarke et al. (2008). For the present analysis, we adopt the GCAM's current core assumptions for the cost and performance characteristics of wind technologies for the electricity sector: onshore, offshore, and onshore with co-located storage. Offshore resource supply curves are from the above assessment.

Electricity generation in GCAM is broken out into four load regimes: base, intermediate, subpeak, and peak. Generation technologies compete to provide power in each of the four load regimes according to the load factor associated with the respective segments - as high as $83 \%$ for baseload down to $6 \%$ for peak producers. Due to the variability of wind production, high penetrations of wind capacity are assumed to be paired with gas turbine backup, with the backup requirement increasing exponentially with penetration (Figure 10). While there is a generic low-emissions alternative backup technology, it is much more expensive than the gas turbine and rarely gains market share. The backup ratio (MW of backup technology required per MW of wind) ramps up quickly between $20 \%$ and $30 \%$ wind capacity.

For this study, we compare wind penetration in a reference case and a case assuming a carbon policy. Both scenarios see some technological improvements in the cost and performance of wind (and other technologies) over time. For onshore wind, GCAM assumes capital costs from EERE GPRA $2008^{8}$ and operation and maintenance

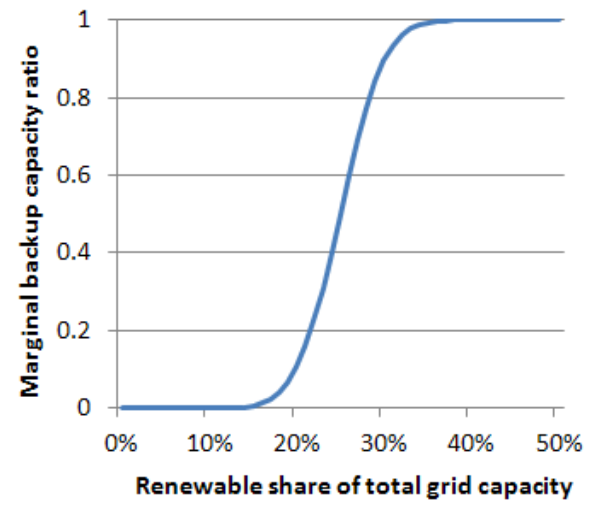

Figure 10. Backup ratio for variable renewable power as a function of penetration

\footnotetext{
${ }^{8}$ U.S. DOE, division of Energy Efficiency and Renewable Energy, Government Performance and Results Act, 2008 Report. http://www1.eere.energy.gov/ba/pba/2008 benefits.html
} 
(O\&M) costs and improvement rates from the Department of Energy's 20\% Wind Energy by 2030 report. $^{9}$ Onshore wind resource is a PNNL-derived supply curve.

The costs for offshore turbines are from the same report, and include turbines, towers, foundations, installation, and interconnection fees. 2020 cost assumptions are presented in Table 3. Transmission costs for both onshore and offshore wind are included in a parameterized way and are based on the $20 \%$ Wind Energy by 2030 report. Base transmission costs are $\$ 510 / \mathrm{kW}$ and increase with penetration.

Table 3. Onshore and Offshore Wind Cost and Performance Assumptions

\begin{tabular}{lll} 
& \multicolumn{2}{l}{$\begin{array}{l}\mathbf{2 0 2 0} \text { Wind Technology } \\
\text { Assumptions }\end{array}$} \\
\cline { 2 - 3 } & Onshore & Offshore \\
\hline Capital $(2007 \$ / \mathrm{kW})$ & 1,140 & 2,181 \\
Fixed O\&M $(2007 \$ / \mathrm{kW}$-year $)$ & 11.7 & 15.2 \\
Var O\&M $(2007 \$ / \mathrm{MWh})$ & 0.5 & 1.4 \\
Capacity Factor & $45 \%$ & $47 \%$ \\
\hline
\end{tabular}

The representative policy case is a modified Energy Modeling Forum-22 (EMF-22) scenario: a carbon-mitigation scenario with a target of $3.7 \mathrm{~W} / \mathrm{m}^{2}$ of radiative forcing at the end of the century, roughly equivalent to $550 \mathrm{ppmv} \mathrm{CO}_{2}$-equivalent. In the scenario, the majority of developed regions begin mitigation efforts in 2012, and the remaining regions phase in their efforts over the course of the century.


Figure 11. Global electricity generation by source; reference (left) and policy (right) scenarios

Comparing electric-sector results between the two scenarios, shown in Figure 11, total electric demand is higher in the carbon policy scenario than in the reference due to electrification of other sectors. Of the roughly 60 EJ of additional demand in 2095, eight are derived from wind power: wind output increased from $28 \mathrm{EJ}$ to $36 \mathrm{EJ}$ for that year. Wind is but one of several carbon-abatement options available in the electric sector, along with carbon-capture and storage (CCS), nuclear, solar, coal/gas fuel-switching, and biopower. Biomass with CCS, a negative-

${ }^{9}$ http://20percentwind.org/ 
emissions technology, becomes one of the dominant electricity-providers in the second half of the century.

Of the total wind production, the vast majority is from onshore turbines. In the reference case, only $6 \%$ of wind energy is produced by offshore turbines. That measure increases to $17 \%$ in the policy case, when offshore wind claims a majority of the increase in penetration (Figure 12).
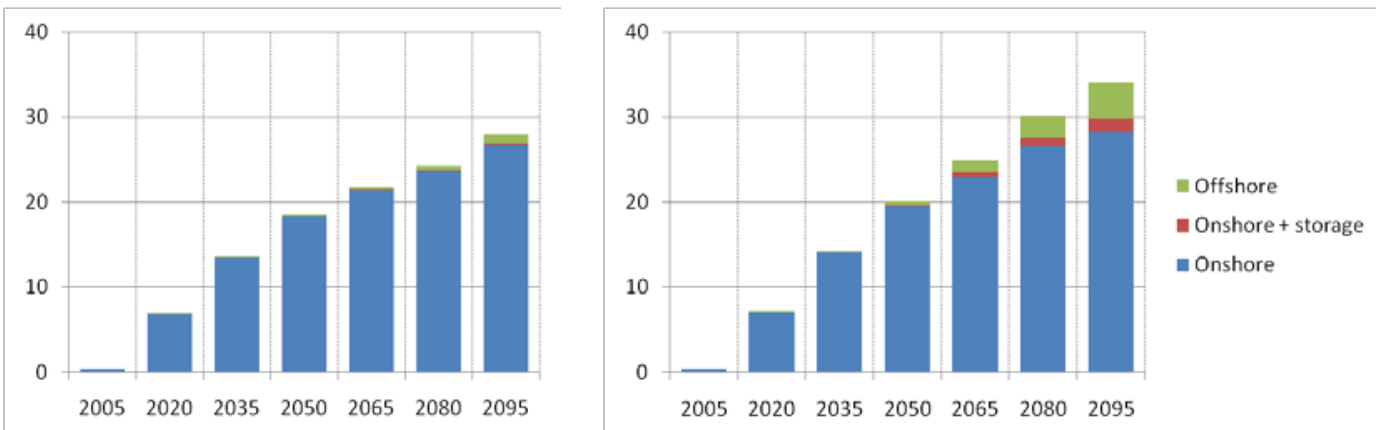

Figure 12. Global wind production (EJ) by type; reference (left) and policy (right) scenarios

We executed several additional scenarios to test the initial scenarios' sensitivity to a few of the assumptions. Lowering all wind technology costs by $20 \%$ produced a substantial increase in total wind production over the base policy scenario (Figure 13). The increase in offshore wind production was even larger: onshore wind production is slightly lower in the policy+advanced technology scenario than in the policy baseline scenario. With the lower prices, less onshore resource depletion is necessary to reach equilibrium between onshore and offshore wind: the better resource offshore nearly offsets the higher costs.

To study the impact of the intermittency assumptions on wind penetration, additional sensitivity scenarios involved delaying the intermittency penalty. Rather than the backup requirement ramping in strongly from $20 \%$ to $30 \%$ of energy from variable renewables, the two intermittency sensitivities push the ramp back by 5 or 15 percentage points. Both relaxed scenarios result in increased wind penetration, but as seen in Table 4, the increases are not fully described by the backup penalty. That is, a delay in the onset of the

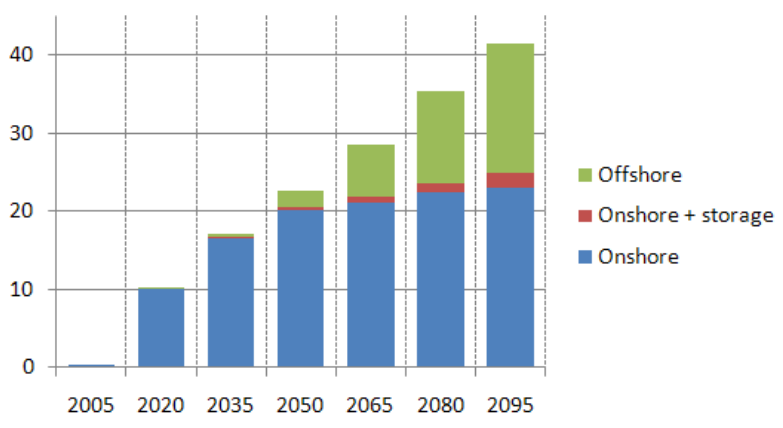

Figure 13. Global wind production (EJ) by type; policy+advanced technology scenario backup requirement from $20 \%$ to $25 \%$ does not result in a commensurate increase in variable renewable penetration. Resource depletion, transmission, load-curve shape, and other factors influence penetration as well. 
Table 4. Sensitivity of Wind and Solar Power to the Intermittency Curve. The policy case ramps the backup requirement in between $20 \%$ and $30 \%$; the advanced policy cases delay that ramp to $25 \%-35 \%$ and $35 \%-45 \%$ for advanced policy 1 and 2 , respectively.

2095 Fraction of Electricity from Variable Renewables (EJ/EJ)

\begin{tabular}{lrrrr} 
& Reference & Policy & Adv. Policy 1 & Adv. Policy 2 \\
\hline Onshore & 0.081 & 0.077 & 0.096 & 0.13 \\
Offshore & 0.003 & 0.011 & 0.009 & 0.006 \\
Solar & 0.10 & 0.12 & 0.12 & 0.12 \\
\hline Total & 0.19 & 0.21 & 0.22 & 0.25 \\
\hline
\end{tabular}




\section{Conclusions and Further Research}

These initial results indicate that more accurate wind resource potential estimates are an important element of ongoing climate mitigation scenario analysis and may have important impacts on the energy mix results and overall economic calculus of mitigation options. Further research with a comprehensive set of models that incorporate improvements in model inputs will improve our understanding of how renewable resources can contribute to GHG mitigation efforts. Input improvements include next-generation potential estimates and supply curves for onshore wind, solar, geothermal, and biomass resources in addition to offshore wind as described here, as well as methodologies for representing the geospatial economics and variability considerations of renewable energy technologies.

Resource assessments, such as that described here, are vital for informing models and still have room for improvement. Consistent, high-quality, global resource assessments require highresolution modeled or measured datasets with complete global coverage that are only now becoming available. Processing the measurements to create resource supply curves also requires new techniques and knowledge to produce assessments that accurately describe resource quality, quantity, and accessibility while properly accounting for such factors as proper exclusion of areas due to protected status or land-use competition. The assessment discussed in this paper takes steps in that direction both in the dataset chosen and the processing steps, but work remains to be done, in particular on downscaling onshore data to account for terrain effects and on developing metrics that can describe accessibility of particular sites in a robust way. 


\section{Bibliography}

Badger, J; Ejsing Jørgensen, H. (2011). "A high resolution global wind atlas - improving estimation of world wind resources." Energy Systems and Technologies for the Coming Century: Proceedings. Risø-R-1776(EN). Roskilde: Technical University of Denmark, pp. 215-225.

Clarke, L; Kyle, P; Wise, M; Calvin, K; Edmonds, J. (2009). $\mathrm{CO}_{2}$ Emissions Mitigation and Technological Advance: An Updated Analysis of Advanced Technology Scenarios. (Scenarios updated January 2009). PNNL-18075. Richland, WA: Pacific Northwest National Laboratory.

Hoogwijk, M., et al. (2004). "Assessment of the global and regional, geographic, technical and economic potential of onshore wind energy." Energy Economics (26), pp. 889-919.

IPCC (2011). IPCC Special Report on Renewable Energy Sources and Climate Change Mitigation. Prepared by Working Group III of the Intergovernmental Panel on Climate Change [O. Edenhofer, R. Pichs-Madruga, Y. Sokona, K. Seyboth, P. Matschoss, S. Kadner, T. Zwickel, P. Eickemeier, G. Hansen, S. Schlömer, C. von Stechow (eds)]. Cambridge, United Kingdom and New York, NY: Cambridge University Press, 1075 pp.

Landberg, L.; Myllerup, L.; et al. (2003). "Wind Resource Estimation—An Overview." Wind Energy (6:3), pp. 261-271.

Lu, X.; McElroy, M.; Kiviluouma, J. (2009). "Global potential for wind-generated electricity.” Proc. Natl. Acad. Sci. (106), 10933.

Musial, W.; Ram, B. (2010). Large-Scale Offshore Wind Power in the United States: Assessment of Opportunities and Barriers. NREL/TP-500-40745. Golden, CO: National Renewable Energy Laboratory.

Schwartz, M.; Heimiller, D.; Haymes, S. (2010). Assessment of Offshore Wind Energy Resources for the United States. NREL/TP-500-45889. Golden, CO: National Renewable Energy Laboratory. 


\section{Appendix A: Global Wind Potential Supply Curves by Country, Class}

(Binned by Annual Average Capacity Factor), and Depth (Quantities in GW)

Shallow $(0-30 \mathrm{~m})$

\begin{tabular}{|c|c|c|c|c|c|c|c|c|c|c|c|c|c|c|c|c|}
\hline Country & $\begin{array}{c}34 \%- \\
38 \%\end{array}$ & $\begin{array}{c}38 \%- \\
42 \%\end{array}$ & $\begin{array}{l}42 \%- \\
46 \%\end{array}$ & $>46 \%$ & Total & $\begin{array}{c}34 \%- \\
38 \%\end{array}$ & $\begin{array}{r}38 \%- \\
42 \%\end{array}$ & $\begin{array}{r}42 \%- \\
46 \%\end{array}$ & $>46 \%$ & Total & $\begin{array}{r}34 \%- \\
38 \%\end{array}$ & $\begin{array}{c}38 \%- \\
42 \%\end{array}$ & $\begin{array}{r}42 \%- \\
46 \%\end{array}$ & $>46 \%$ & Total & (GW) \\
\hline Albania & 0 & 0 & 0 & 0 & 0 & 0.02 & 0 & 0 & 0 & 0.02 & 13.1 & 14.78 & 0 & 0 & 27.88 & 27.9 \\
\hline Algeria & 0 & 0 & 0 & 0 & 0 & 0.08 & 0 & 0 & 0 & 0.08 & 5.18 & 0 & 0 & 0 & 5.18 & 5.26 \\
\hline Angola & 0 & 0 & 0.02 & 0 & 0.02 & 0 & 0.66 & 0.48 & 0 & 1.14 & 0 & 7.52 & 16.86 & 1.18 & 25.56 & 26.72 \\
\hline Argentina & 2.34 & 47.6 & 220.6 & 25.94 & 296.48 & 3.6 & 74.26 & 385 & 48.82 & 511.68 & 44.28 & 255.56 & $1,053.6$ & 849.22 & $2,202.6$ & 3010.8 \\
\hline Australia & 159.02 & 257.74 & 268.1 & 157.2 & 842.06 & 94.2 & 342.56 & 309.26 & 483.24 & 1229.3 & 80.88 & 255.38 & $1,199.1$ & 1841.9 & $3,377.3$ & $5,448.6$ \\
\hline Bahamas & 90.36 & 36 & 0.06 & 0 & 126.42 & 4.14 & 5.28 & 0.02 & 0 & 9.44 & 99.62 & 137.3 & 9.26 & 0 & 246.18 & 382.04 \\
\hline Barbados & 0 & 0 & 0 & 0 & 0 & 0 & 0 & 0 & 0 & 0 & 0 & 0 & 0.14 & 16.4 & 16.54 & 16.54 \\
\hline Belgium & 0 & 0 & 0 & 12.48 & 12.48 & 0 & 0 & 0 & 3.18 & 3.18 & 0 & 0 & 0 & 0 & 0 & 15.66 \\
\hline Belize & 0 & 2.8 & 0.66 & 0.04 & 3.5 & 0 & 0.06 & 0.12 & 0 & 0.18 & 0 & 3.02 & 9.5 & 0 & 12.52 & 16.2 \\
\hline Brazil & 34.4 & 197.66 & 481.12 & 200.52 & 913.7 & 21.16 & 152.62 & 373.72 & 158.72 & 706.22 & 193.32 & 333.94 & 307.28 & 514.46 & 1,349 & $2,968.9$ \\
\hline Bulgaria & 1.4 & 0 & 0 & 0 & 1.4 & 5.74 & 0.54 & 0 & 0 & 6.28 & 27.02 & 1.36 & 0 & 0 & 28.38 & 36.06 \\
\hline Cameroon & 0.58 & 0 & 0 & 0 & 0.58 & 0 & 0 & 0 & 0 & 0 & 0 & 0 & 0 & 0 & 0 & 0.58 \\
\hline Canada & 0.1 & 1.2 & 9.44 & 36.94 & 47.68 & 2.06 & 9.74 & 85.58 & 223.64 & 321.02 & 17.42 & 329.2 & 529.98 & 3639.1 & $4,515.7$ & $4,884.4$ \\
\hline Cape Verde & 0 & 0.62 & 0 & 0 & 0.62 & 0 & 1.76 & 0.02 & 0 & 1.78 & 0.12 & 21.72 & 1.6 & 0 & 23.44 & 25.84 \\
\hline Chile & 0 & 0 & 1.32 & 11.52 & 12.84 & 0 & 0.18 & 5.78 & 28.86 & 34.82 & 6.42 & 59.1 & 170.24 & 358.4 & 594.16 & 641.82 \\
\hline China & 71.86 & 116.68 & 31.42 & 96.3 & 316.26 & 76.2 & 318.28 & 149.54 & 212.42 & 756.44 & 55.12 & 202.3 & 564.6 & 305.12 & $1,127.1$ & $2,199.8$ \\
\hline Colombia & 0.26 & 0.04 & 0 & 18.66 & 18.96 & 1.16 & 0.26 & 0.02 & 19.98 & 21.42 & 7.66 & 8.5 & 4.2 & 93.86 & 114.22 & 154.6 \\
\hline Costa Rica & 0 & 0 & 0.1 & 0 & 0.1 & 0 & 0 & 0.14 & 0 & 0.14 & 4.16 & 15.78 & 7.66 & 0 & 27.6 & 27.84 \\
\hline Croatia & 0 & 0 & 0 & 0 & 0 & 0 & 0 & 0 & 0 & 0 & 0 & 0 & 0 & 0 & 0 & 0 \\
\hline
\end{tabular}




\begin{tabular}{|c|c|c|c|c|c|c|c|c|c|c|c|c|c|c|c|c|}
\hline Cuba & 29.28 & 11.18 & 0 & 0 & 40.46 & 1.94 & 0.92 & 0 & 0 & 2.86 & 48.78 & 34.24 & 3.22 & 0 & 86.24 & 129.56 \\
\hline Denmark & 0 & 0 & 0 & 64.44 & 64.44 & 0 & 0 & 0.98 & 162.56 & 163.54 & 0 & 0 & 7.04 & 20.84 & 27.88 & 255.86 \\
\hline $\begin{array}{l}\text { Dominican } \\
\text { Republic }\end{array}$ & 0 & 0.06 & 18.72 & 0.18 & 18.96 & 0 & 0.08 & 1.5 & 0.02 & 1.6 & 0 & 2.32 & 41.26 & 8.54 & 52.12 & 72.68 \\
\hline Ecuador & 0.3 & 0 & 0 & 0 & 0.3 & 1.26 & 0 & 0 & 0 & 1.26 & 0.16 & 0 & 0 & 0 & 0.16 & 1.72 \\
\hline Egypt & 0 & 0 & 0.38 & 0 & 0.38 & 0 & 0 & 0.32 & 0 & 0.32 & 19.2 & 35.72 & 16.52 & 0 & 71.44 & 72.14 \\
\hline Eritrea & 0.1 & 0.78 & 0.44 & 0 & 1.32 & 3.04 & 12.46 & 0.74 & 0 & 16.24 & 3.18 & 12.78 & 0.78 & 0 & 16.74 & 34.3 \\
\hline Estonia & 0 & 0 & 3.94 & 0 & 3.94 & 0 & 0 & 15.12 & 0 & 15.12 & 0 & 0 & 31.38 & 0 & 31.38 & 50.44 \\
\hline Fiji & 1.84 & 22.22 & 11.68 & 0 & 35.74 & 1.06 & 16.88 & 9.38 & 0 & 27.32 & 0.08 & 98.8 & 149.9 & 0 & 248.78 & 311.84 \\
\hline Finland & 0 & 0.3 & 4.48 & 1.52 & 6.3 & 0 & 2 & 24.64 & 2.74 & 29.38 & 0 & 5.18 & 90.18 & 0.24 & 95.6 & 131.28 \\
\hline France & 0 & 4.48 & 17.4 & 24.54 & 46.42 & 0 & 25.84 & 46.72 & 62.16 & 134.72 & 2.78 & 49.08 & 205.84 & 310.38 & 568.08 & 749.22 \\
\hline French Polynesia & 0.2 & 1.54 & 0.98 & 0 & 2.72 & 0.14 & 0.46 & 0.76 & 0 & 1.36 & 5.12 & 39.86 & 14.64 & 0.84 & 60.46 & 64.54 \\
\hline Germany & 0 & 0 & 0 & 27.54 & 27.54 & 0 & 0 & 0 & 96.8 & 96.8 & 0 & 0 & 0 & 0 & 0 & 124.34 \\
\hline Greece & 0 & 0 & 0.1 & 0 & 0.1 & 0.1 & 0 & 0.02 & 1.76 & 1.88 & 51.8 & 116.5 & 164.36 & 33.02 & 365.68 & 367.66 \\
\hline $\begin{array}{l}\text { Guadeloupe and } \\
\text { Martinique }\end{array}$ & 0 & 0 & 0.02 & 0.06 & 0.08 & 0 & 0 & 0.1 & 0.5 & 0.6 & 0 & 0 & 19.98 & 7.18 & 27.16 & 27.84 \\
\hline Guatemala & 0 & 0.64 & 0 & 0 & 0.64 & 0 & 0.14 & 0 & 0 & 0.14 & 0 & 0.78 & 0 & 0 & 0.78 & 1.56 \\
\hline Guyana & 46.52 & 55.7 & 0 & 0 & 102.22 & 0.94 & 105.46 & 0 & 0 & 106.4 & 0 & 82.22 & 1.9 & 0 & 84.12 & 292.74 \\
\hline Haiti & 0 & 0.72 & 0 & 0 & 0.72 & 0 & 0.14 & 0 & 0 & 0.14 & 0 & 4.86 & 4.54 & 0.48 & 9.88 & 10.74 \\
\hline Honduras & 0 & 7.44 & 141.84 & 0.68 & 149.96 & 0 & 1.06 & 61.12 & 0.68 & 62.86 & 0 & 12.64 & 156.6 & 0.06 & 169.3 & 382.12 \\
\hline Iceland & 0 & 0 & 0 & 1.52 & 1.52 & 0 & 0 & 0 & 17.9 & 17.9 & 0 & 0 & 0 & $1,440.0$ & $1,440.0$ & $1,459.4$ \\
\hline India & 9.6 & 11.6 & 13.06 & 3.6 & 37.86 & 10.56 & 3.86 & 15.58 & 5.72 & 35.72 & 29.04 & 18.2 & 36.82 & 3.98 & 88.04 & 161.62 \\
\hline Indonesia & 70.08 & 120.92 & 268.08 & 0 & 459.08 & 75.88 & 240.52 & 7.82 & 0 & 324.22 & 276.82 & 321.06 & 19.9 & 0 & 617.78 & $1,401.1$ \\
\hline Ireland & 0 & 0 & 0 & 5.1 & 5.1 & 0 & 0 & 0 & 34.28 & 34.28 & 0 & 0 & 0 & 770.28 & 770.28 & 809.66 \\
\hline Italy & 0 & 0.2 & 0 & 0 & 0.2 & 1.2 & 2.9 & 0 & 0 & 4.1 & 188.34 & 150.2 & 0 & 0 & 338.54 & 342.84 \\
\hline
\end{tabular}




\begin{tabular}{|c|c|c|c|c|c|c|c|c|c|c|c|c|c|c|c|c|}
\hline Jamaica & 0 & 11.44 & 22.68 & 4.56 & 38.68 & 0 & 2.26 & 4.1 & 1.24 & 7.6 & 0.68 & 38.92 & 36.02 & 18.64 & 94.26 & 140.54 \\
\hline Japan & 1.48 & 0.48 & 1.22 & 2.24 & 5.42 & 2.16 & 8.56 & 8.68 & 19.46 & 38.86 & 31.64 & 189.9 & 941.74 & $1,252.0$ & $2,415.2$ & $2,459.5$ \\
\hline Kenya & 0 & 2.12 & 0 & 0 & 2.12 & 0 & 1.9 & 0 & 0 & 1.9 & 13.66 & 99.4 & 0 & 0 & 113.06 & 117.08 \\
\hline Latvia & 0 & 0 & 10.08 & 0 & 10.08 & 0 & 0 & 33.46 & 0 & 33.46 & 0 & 0 & 61.38 & 0 & 61.38 & 104.92 \\
\hline Libya & 0 & 0.06 & 0 & 0 & 0.06 & 0.62 & 0.82 & 0 & 0 & 1.44 & 13.4 & 12.68 & 0 & 0 & 26.08 & 27.58 \\
\hline Lithuania & 0 & 0 & 1.04 & 0 & 1.04 & 0 & 0.08 & 14.94 & 0 & 15.02 & 0 & 0 & 10.9 & 0 & 10.9 & 26.96 \\
\hline Madagascar & 2.82 & 2.46 & 1.42 & 10.82 & 17.52 & 8.36 & 14.74 & 1.8 & 34.34 & 59.24 & 8.18 & 41.12 & 14.08 & 107.68 & 171.06 & 247.82 \\
\hline Malta & 0 & 0 & 0 & 0 & 0 & 0 & 0 & 0 & 0 & 0 & 39.7 & 0 & 0 & 0 & 39.7 & 39.7 \\
\hline Mauritania & 15.32 & 0.48 & 0 & 0 & 15.8 & 1.8 & 0 & 0 & 0 & 1.8 & 12.06 & 0.8 & 0 & 0 & 12.86 & 30.46 \\
\hline Mauritius & 0 & 0 & 0 & 8.84 & 8.84 & 0 & 0 & 0 & 48.46 & 48.46 & 0 & 0 & 0.14 & 236.26 & 236.4 & 293.7 \\
\hline Mexico & 64.16 & 130.02 & 3.4 & 0.66 & 198.24 & 82.74 & 279.44 & 7.1 & 3.22 & 372.5 & 193.34 & 290.88 & 105.98 & 8.54 & 598.74 & $1,169.5$ \\
\hline Morocco & 0.06 & 0.52 & 0.64 & 0 & 1.22 & 15.06 & 11.94 & 5.1 & 0 & 32.1 & 65.88 & 92.4 & 51.96 & 0 & 210.24 & 243.56 \\
\hline Mozambique & 28.88 & 1.26 & 2.76 & 0 & 32.9 & 79.68 & 2.48 & 10.48 & 0 & 92.64 & 83 & 73.64 & 209.18 & 18.6 & 384.42 & 509.96 \\
\hline Namibia & 0 & 0 & 0 & 0 & 0 & 0.02 & 0.02 & 0.16 & 0 & 0.2 & 58.7 & 130.2 & 89.92 & 1.56 & 280.38 & 280.58 \\
\hline Netherlands & 0 & 0 & 0 & 110.14 & 110.14 & 0 & 0 & 0 & 150.9 & 150.9 & 0 & 0 & 0 & 0.04 & 0.04 & 261.08 \\
\hline $\begin{array}{l}\text { Netherlands } \\
\text { Antilles }\end{array}$ & 0 & 0 & 0 & 0.02 & 0.02 & 0 & 0 & 0 & 0.98 & 0.98 & 0 & 0 & 0 & 27.14 & 27.14 & 28.14 \\
\hline New Caledonia & 0 & 0.06 & 19.86 & 0 & 19.92 & 0 & 0.06 & 36.26 & 0 & 36.32 & 0 & 1 & 297.76 & 0.46 & 299.22 & 355.46 \\
\hline New Zealand & 2.94 & 6.9 & 1.24 & 24.32 & 35.4 & 7.44 & 14.3 & 7.86 & 87.64 & 117.24 & 33.44 & 131.16 & 357.34 & $2,748.1$ & $3,270.1$ & $3,422.7$ \\
\hline Nicaragua & 6.04 & 27.02 & 167.96 & 0 & 201.02 & 7.84 & 5.22 & 11.26 & 0 & 24.32 & 14.52 & 42.28 & 39.66 & 1.42 & 97.88 & 323.22 \\
\hline Nigeria & 0 & 0 & 0 & 0 & 0 & 0 & 0 & 0 & 0 & 0 & 0 & 0 & 0 & 0 & 0 & 0 \\
\hline North Korea & 0.96 & 0 & 0 & 0 & 0.96 & 9.48 & 0 & 0 & 0 & 9.48 & 14.86 & 0 & 0 & 0 & 14.86 & 25.3 \\
\hline $\begin{array}{l}\text { Northern Mariana } \\
\text { Islands and Guam }\end{array}$ & 0 & 0 & 0.98 & 0 & 0.98 & 0 & 0 & 0.3 & 0 & 0.3 & 0 & 0 & 26.16 & 0 & 26.16 & 27.44 \\
\hline Norway & 0 & 0 & 0.46 & 4.96 & 5.42 & 0 & 0.3 & 14.54 & 148.46 & 163.3 & 0.72 & 15.86 & 99.44 & $3,350.0$ & $3,466.0$ & $3,634.8$ \\
\hline
\end{tabular}




\begin{tabular}{|c|c|c|c|c|c|c|c|c|c|c|c|c|c|c|c|c|}
\hline Oman & 0.06 & 0.3 & 0.02 & 0 & 0.38 & 0.26 & 2.26 & 0.02 & 0 & 2.54 & 2.7 & 5.8 & 0.14 & 0 & 8.64 & 11.56 \\
\hline Panama & 0.28 & 0.38 & 0 & 0 & 0.66 & 0.22 & 0.98 & 0 & 0 & 1.2 & 5.9 & 4.1 & 0 & 0 & 10 & 11.86 \\
\hline Papua New Guinea & 10.82 & 102.48 & 93.64 & 1.24 & 208.18 & 11.22 & 33.64 & 3.18 & 0.02 & 48.06 & 55.38 & 149.56 & 36.12 & 0.96 & 242.02 & 498.26 \\
\hline Peru & 0 & 0 & 0 & 0 & 0 & 0 & 0 & 0 & 0 & 0 & 0.02 & 0 & 0 & 0 & 0.02 & 0.02 \\
\hline Philippines & 3.92 & 30.24 & 0.68 & 0.16 & 35 & 0.62 & 22.8 & 0.86 & 0.42 & 24.7 & 12.28 & 91.8 & 32.42 & 71.46 & 207.96 & 267.66 \\
\hline Poland & 0.96 & 0.02 & 12.66 & 0 & 13.64 & 0 & 0 & 32.28 & 0 & 32.28 & 0 & 0 & 67.84 & 0 & 67.84 & 113.76 \\
\hline Portugal & 0 & 0.12 & 0.54 & 0 & 0.66 & 0 & 7.18 & 4.14 & 0 & 11.32 & 17.04 & 26.36 & 113.86 & 0 & 157.26 & 169.24 \\
\hline $\begin{array}{l}\text { Puerto Rico and } \\
\text { U.S. Virgin Islands }\end{array}$ & 0 & 0 & 1.7 & 0 & 1.7 & 0 & 0 & 3.1 & 0.18 & 3.28 & 0 & 0 & 37.38 & 4.1 & 41.48 & 46.46 \\
\hline Reunion & 0 & 0 & 0.22 & 0 & 0.22 & 0 & 0 & 0.16 & 0 & 0.16 & 0 & 0 & 0.9 & 1.38 & 2.28 & 2.66 \\
\hline Romania & 2.82 & 0 & 0 & 0 & 2.82 & 27.62 & 19.72 & 0 & 0 & 47.34 & 4.86 & 74.08 & 0 & 0 & 78.94 & 129.1 \\
\hline Russia & 7.3 & 70.9 & 47.6 & 138.22 & 264.02 & 30.48 & 90.8 & 164.52 & 586.46 & 872.26 & 217.62 & 622.48 & $1,474.9$ & 3,817 & $6,132.0$ & 7268.3 \\
\hline Samoa & 0 & 0 & 0.02 & 0 & 0.02 & 0 & 0.04 & 0.08 & 0 & 0.12 & 0 & 5 & 2.98 & 0 & 7.98 & 8.12 \\
\hline Saudi Arabia & 0 & 0 & 0 & 0 & 0 & 0 & 0 & 0 & 0 & 0 & 15.06 & 21.3 & 0 & 0 & 36.36 & 36.36 \\
\hline Solomon Islands & 0.04 & 2.1 & 1.24 & 0 & 3.38 & 0.02 & 1.54 & 0.42 & 0 & 1.98 & 22.6 & 36.68 & 7.26 & 0 & 66.54 & 71.9 \\
\hline Somalia & 0 & 0 & 0.42 & 0.92 & 1.34 & 0 & 0 & 7.98 & 19.08 & 27.06 & 4.84 & 70.42 & 70.3 & 157.02 & 302.58 & 330.98 \\
\hline South Africa & 0.12 & 0.02 & 0 & 1.28 & 1.42 & 0.18 & 1.2 & 0.64 & 17.5 & 19.52 & 46.54 & 111.8 & 143.48 & 576.94 & 878.76 & 899.7 \\
\hline South Korea & 0.14 & 0.36 & 1.46 & 0 & 1.96 & 25.56 & 33.06 & 9.94 & 0.14 & 68.7 & 44.9 & 129.8 & 190.26 & 65.7 & 430.66 & 501.32 \\
\hline Spain & 3.04 & 8.08 & 3.22 & 7.02 & 21.36 & 2.3 & 4.22 & 1.98 & 1.42 & 9.92 & 100.94 & 77.88 & 27.68 & 79.34 & 285.84 & 317.12 \\
\hline Sri Lanka & 9.22 & 12.9 & 11.86 & 2 & 35.98 & 4.58 & 13.38 & 3.68 & 2.68 & 24.32 & 13.12 & 19.48 & 27.38 & 5.9 & 65.88 & 126.18 \\
\hline Suriname & 61.08 & 2.96 & 0 & 0 & 64.04 & 84.5 & 37.54 & 0 & 0 & 122.04 & 3.04 & 127.8 & 0 & 0 & 130.84 & 316.92 \\
\hline Sweden & 2.16 & 0.92 & 18.72 & 0 & 21.8 & 3.92 & 13.6 & 120.64 & 0 & 138.16 & 0.44 & 17.32 & 239.58 & 2.3 & 259.64 & 419.6 \\
\hline Taiwan & 0 & 0 & 0 & 44.74 & 44.74 & 0 & 0 & 0.1 & 68.96 & 69.06 & 0 & 0.18 & 39.4 & 498.9 & 538.48 & 652.28 \\
\hline Tanzania & 0.62 & 2.74 & 0 & 0 & 3.36 & 0.56 & 1 & 0 & 0 & 1.56 & 40.06 & 5.74 & 0 & 0 & 45.8 & 50.72 \\
\hline
\end{tabular}




\begin{tabular}{|c|c|c|c|c|c|c|c|c|c|c|c|c|c|c|c|c|}
\hline $\begin{array}{l}\text { Trinidad and } \\
\text { Tobago }\end{array}$ & 2.3 & 2.7 & 2.82 & 0 & 7.82 & 0 & 2.24 & 33.6 & 0 & 35.84 & 0.04 & 12.08 & 80.96 & 0 & 93.08 & 136.74 \\
\hline Tunisia & 1.62 & 0.96 & 0 & 0 & 2.58 & 18.12 & 8.54 & 0.56 & 0 & 27.22 & 58.86 & 174.72 & 2.86 & 0 & 236.44 & 266.24 \\
\hline Turkey & 0 & 0 & 0 & 0.02 & 0.02 & 0 & 0 & 0 & 0.14 & 0.14 & 0 & 0.48 & 0.94 & 2.9 & 4.32 & 4.48 \\
\hline Ukraine & 51.72 & 94.56 & 0 & 0 & 146.28 & 19.56 & 64.82 & 0 & 0 & 84.38 & 17.22 & 62.58 & 0 & 0 & 79.8 & 310.46 \\
\hline United Kingdom & 0 & 0 & 53.88 & 113.96 & 167.84 & 0 & 0 & 46.28 & 417.48 & 463.76 & 0 & 0 & 0.54 & $1,840.9$ & $1,841.4$ & 2473 \\
\hline United States (48) & 33.16 & 128.34 & 56.88 & 15.68 & 234.06 & 7.8 & 285.56 & 52 & 49.22 & 394.58 & 107.86 & 700.18 & 404.82 & 248.2 & $1,461.1$ & $2,089.7$ \\
\hline Uruguay & 0 & 121.32 & 26.1 & 0 & 147.42 & 0 & 86.1 & 7.64 & 0 & 93.74 & 0 & 59.48 & 51 & 5.4 & 115.88 & 357.04 \\
\hline Vanuatu & 0 & 0 & 0.06 & 0 & 0.06 & 0 & 0 & 0.1 & 0 & 0.1 & 0 & 21.58 & 83.24 & 11.68 & 116.5 & 116.66 \\
\hline Venezuela & 10.58 & 23.4 & 1.1 & 55.24 & 90.32 & 10.14 & 62.76 & 20.08 & 14.78 & 107.76 & 29.98 & 159.2 & 108.98 & 73.22 & 371.38 & 569.46 \\
\hline Viet Nam & 47.12 & 54.64 & 69.1 & 25.58 & 196.44 & 75.58 & 70.78 & 74.46 & 59.2 & 280.02 & 81.02 & 122.06 & 101.3 & 161.36 & 465.74 & 942.2 \\
\hline Western Sahara & 10.02 & 17.26 & 2.8 & 0 & 30.08 & 27 & 70.36 & 17.52 & 0 & 114.88 & 9.7 & 158.44 & 96.52 & 0 & 264.66 & 409.62 \\
\hline Yemen & 1.02 & 2.96 & 3.06 & 0 & 7.04 & 1.8 & 7.46 & 15.16 & 0 & 24.42 & 12.04 & 13.34 & 74.86 & 0 & 100.24 & 131.7 \\
\hline Assigned Total & 901.02 & $1,761.6$ & $2,137.5$ & $1,261.4$ & $6,061.5$ & 871.72 & $2,602.6$ & $2,271.6$ & $3,296.4$ & $9,042.3$ & $2,687.4$ & $6,871.9$ & 10,698 & 25,611 & 45,868 & 60,972 \\
\hline Global Total & 973.4 & $1,881.9$ & $2,332.8$ & $1,740.5$ & $6,928.7$ & 952.08 & $2,689.0$ & $2,395.3$ & $4,419.3$ & 10,455 & $2,935.4$ & $7,595.1$ & 11,743 & 34,511 & 56,785 & 74,169 \\
\hline Unassigned Total $^{10}$ & 72.38 & 120.34 & 195.32 & 479.1 & 867.14 & 80.36 & 86.42 & 123.64 & $1,122.9$ & $1,413.4$ & 248 & 723.28 & $1,044.6$ & $8,900.4$ & 10,916 & 13,197 \\
\hline
\end{tabular}

\footnotetext{
${ }^{10}$ Roughly one-third of the unassigned resource is ascribed to Alaska.
} 